Table 2. cAMP content of isolated Petunia mesophyll protoplasts $2 \mathrm{~h}$ after feeding cAMP to intact leaf tissue (in pmol/mg protoplast mass)

Control cAMP fed

100 ppm cAMP fed by vacuum infiltration $0.3 \quad 7.5$

1000 ppm cAMP fed through petioles

$1.3 \quad 51.6$

\section{Evidence of Cyclic-AMP Uptake into Plant Cells}

\author{
J. Wiedmaier and U. Kull \\ Biologisches Institut der Universität Stuttgart
}

Reports of investigations on the effects of applied cAMP (cyclic 3',5'-adenosine monophosphate) in higher plants are contradictory $[1,2]$. Degradation of cAMP is catalyzed by homogenates from various plant species [3]. However, it has not been convincingly demonstrated that exogenous cAMP penetrates the tissues and enters the cells. All conclusions which have been drawn on the effect or lack of effect of cAMP were based only on the assumption that cAMP penetrated the cell membrane [2]. Using leaf tissues and isolated mesophyll protoplasts of Petunia hybrida as well as leaf tissues of Impatiens sultani we have now shown that applied cAMP does enter cells, where it is rapidly degraded.

Intact leaf tissues were fed cAMP through their petioles $(24 \mathrm{~h})$ or through the leaf surface by vacuum infiltration $(30 \mathrm{~min})$. Protoplasts were prepared and used as previously described [4]. Leaf tissue and protoplasts were extracted and cAMP content determined as reported earlier [5]. Each experiment was run in triplicate. Representative results from one of the three experiments are shown in the tables. In intact tissues cAMP is degraded rapidly (Table 1). By feeding cAMP through the petioles the fluctuations are greater, but the results essentially similar. In Petunia the degradation of

Table 1. cAMP content of leaf tissues after vacuum infiltration of $20 \mathrm{ppm}$ (Impatiens) and $30 \mathrm{ppm}$ (Petunia) cAMP solution, respectively, into intact tissue

\begin{tabular}{|c|c|c|c|c|c|c|c|c|}
\hline $\begin{array}{l}\text { Con- } \\
\text { trol }\end{array}$ & $\begin{array}{l}\text { Leaf } \\
\text { tissue }\end{array}$ & & & & & & & $\begin{array}{l}\text { Con- } \\
\text { trol }\end{array}$ \\
\hline \multicolumn{9}{|l|}{ Impatiens } \\
\hline $\begin{array}{l}\text { Time after } \\
\text { infiltration [h] }\end{array}$ & 0 & 0 & 1 & 2,5 & 5 & 10 & 24 & 24 \\
\hline $\begin{array}{l}\text { cAMP content } \\
\text { [pmol/mg } \\
\text { fresh weight] }\end{array}$ & 0.2 & 7.4 & 3.8 & 2.1 & 0.5 & 0.3 & 0.2 & 0.2 \\
\hline \multicolumn{9}{|l|}{ Petunia } \\
\hline $\begin{array}{l}\text { Time after } \\
\text { infiltration [h] }\end{array}$ & 0 & 0 & 0.5 & 1 & 2 & 5 & & 5 \\
\hline $\begin{array}{l}\text { CAMP content } \\
\text { [pmol/mg } \\
\text { fresh weight] }\end{array}$ & 0.8 & 23.7 & 7.9 & 6.3 & 1.5 & 0.8 & & 0.9 \\
\hline
\end{tabular}

cAMP seems to be quicker than in Impatiens. The production of protoplasts after feeding CAMP took approximately two hours. Therefore it was necessary to apply high concentrations of cAMP to the Petunia tissues to get a significant difference compared to the controls (Table 2). When protoplasts were washed with suspensions medium, the cAMP content of the wash was nearly zero. In one series of experiments, isolated protoplasts were incubated with phosphodiesterase (beef-heart, from Boehringer; incubation time 25 and $40 \mathrm{~min}$, 0.06 units/ml suspension medium). Consequently any cAMP adhering to the outer side of the plasmalemma should be degraded. The content of CAMP measured after this treatment was about $15 \%$ lower than in protoplasts not incubated with the enzyme, but still much higher than in controls. In a final set of experiments involving vacuum infiltration of 250 ppm cAMP into Petunia leaves, chloroplasts were isolated [6] and the CAMP content of the chloroplast preparation measured $1 \mathrm{~h}$ after feeding. The cyclic-nucleotide content in the chloroplasts was ca. 5 times that of controls (control: 0.8; cAMP fed: $4.1 \mathrm{pmol} / \mathrm{mg}$ chloroplast preparation).

From the results, it may be concluded that applied cAMP is taken up into cells and is degraded rapidly not only in intact tissues but also in isolated protoplasts.

The authors are grateful to Miss Barbara Kühn and to Mr. J. Schweizer for help and to Dr. E. Thomas for correction of the English text. The investigations were kindly supported by a grant of the DFG (to U.K.).

Received December 2, 1975

1. Lin, P.P.-C.: Adv. Cyclic Nucl. Res. 4, 439 (1974)

2. Edgerton, M., et al.: Plant Physiol. 55, 695 (1975)

3. Amrhein, N.: Z. Pflanzenphysiol. 72, 249 (1974)

4. Heß, D., Potrykus, L: Naturwissenschaften 59, 273 (1972); Hoffmann, F.: Z. Pflanzenphysio!. 69, 249 (1973); Kull, U., Hoffmann, F.: Biol. plantarum 17, 31 (1975)

5. Kull, U., Kühn, B.: Z. Naturforsch. 30 C, 69 (1975)

6. Nobel, P.S. : Plant Physiol. 42, 1389 (1972) 